\title{
Military Knowledge Transfer Mechanisms: A Passage to Academic World
}

\author{
Dr. Sheikh Shamim Hasnain \\ University of Bedfordshire
}

\begin{abstract}
:
Knowledge Management is an important and significant segment of the Management discipline. Military units and formations could use this valuable asset in their operations. Unfortunately, the academic world could hardly address the knowledge management issues, particularly the knowledge transfers mechanisms in the military context. This paper makes an endeavour to fill up this gray area of the academic world. The exhibited knowledge transfer mechanisms show how military forces use various techniques and mechanisms to transfer knowledge between the knowledge contributors and recipients. The paper will help the business organisations borrow the military knowledge transfer mechanisms. The transfer mechanisms used in military forces presented here provide a deeper understanding of characteristics and nature of the mechanisms; Some of them are different and unique from those of the corporate/business world. Future researchers may empirically examine these mechanisms in military context.
\end{abstract}

Keywords: Knowledge Management, Knowledge Transfer Mechanisms, Military Organisations

\section{Introduction}

Knowledge is inseparable information in context (Galup, Dattero, and Hicks, 2002), related to action (Tiwana, 2002). It is based on some experience (Leonard and Sensiper, 1998). It is a driving force for action and a sphere of influence for professionals. Alavi and Leidner (2001, p. 109) found that, "knowledge is ...the result of cognitive processing... information is converted to knowledge once it is processed in the mind of the individuals" (p. 109), which is essential for the military forces. Knowledge Management is an essential branch and useful tool of management (Edvardsson, 2006) and military forces. In the present world knowledge management could achieve its recognition in all fields. It has a multi-dimensional approach (Chae and Bloodgood, 2006). Tacit knowledge resides inside the human brains and when it is articulated in any form (s), it converts into explicit knowledge (Nonaka and Takeuchi, 1995). Knowledge transfer is an important element of knowledge transfer process. Successful knowledge transfer demands a good vehicle between the knowledge actors. Limited literature (Hasnain, 2016a) could address the issue of knowledge transfer mechanisms in the military context. Hasnain (2016a) has identified face-to-face meetings, military exercises, training, model discussions, military exercises, training, model discussions, military exercise without troops, military logistics exercises, exercise debriefings and demonstrations as the knowledge transfer mechanisms in the military context. Though Hasnain (2016a) could bring and present numerous knowledge transfer mechanisms in the military context, but still many mechanisms remain unaddressed. Further, academic world and knowledge management gurus (Scarbrough, 1995; Taiwana, 2002; Nonaka, \& Takeuchi, 1995; Jasimuddin, 2007; Hensen, Nohria, \& Tierney, 1999) could hardly address the issue of knowledge transfer mechanisms in the military context. This paper makes an endeavour to find out a few unaddressed knowledge transfer mechanisms in the military context.

\section{A Few Knowledge Transfer Mechanisms: A Military Perspective}

If transferred-knowledge is not absorbed by the recipients of knowledge, it means actually knowledge is not transferred (Davenport \&Prusak, 1998). Such cases may be dangerous for the military forces. Knowledge transfer encounters numerous barriers (Hasnain, Jasimuddin and Fuller-Love, 2016). So selection of appropriate transfer mechanisms is crucial for the military forces. Knowledge transfer mechanisms are the vehicles through which knowledge is transferred between the actors (knowledge contributor sand knowledge recipients). Knowledge transfer mechanism may be compared with an element (e. g. media) of the communication model formulated by Shannonand Weaver (1949), where noise may disturb the whole process. 


\section{1 Drum, Bell and Flag}

While describing the method of battle tactics, Sun Tzu (p. 49) informs, "the drum and bell are used, because the voice does not carry; the flag is used to assist the sight. The use of bell, drum, banner and flag to attract the united attention of eye and ear. When all are united, the strong is not left to go forward alone, the cowardly are not free to retreat unrestricted. In this way can a multitude be used. Therefore, in night fighting, beacons and drums are largely used; in day fighting, a great number of banners flags and the enemy's eyes and ears are confounded." Literature (Paul, 2009; Howell, 2003) finds, the use of flags for knowledge transfer is used beyond the military situation also. For example, in 1972, some south-east country-CPPs' (Cyclone Preparedness Centre) volunteers were trained to hoist flags and spread warnings by megaphones among the local communities (Paul, 2009; Howell, 2003). Military organisations use drums, bells and flags for ceremonial purpose also.

By means of drum, bell and flag ${ }^{1}$, the

direction of large forces in battle is possible,

and like unto the direction of small forces - Sun Tzu

\section{2 Intelligence Agency/Corps of Intelligence}

Intelligence agencies and corps of intelligence are the excellent vehicles of knowledge transfer. Many people believe, Sun Tuz (500 BC), the Chinese military strategist, is the father and generator of strategies. "Knowing oneself" and "knowing the enemy" are the two divisions of Sun Tzu's principles (Wong, Maher and Lee, 1998) demanding intelligence. In brief, "Sun Tzu places high priority on intelligence about the actual conditions of the battle, and affords it a strategically decisive role. " (Dimovskiet al., 2012, p. 154). The importance of intelligence is paramount in the warfare. Collect, collate and analysis of information are the prime duties of the intelligence agencies. For instance, British "Intelligence Corps operators collect information from range of sources and evaluate, analyse, integrate and interpret this information to inform command decision making. " (British Army, 2015). Citing the reference from the Bible (New King James Version, Numbers 13:18-20), Hippner (2009) informs about the importance of intelligence and Prophet Moses' techniques of using intelligence. Further, Hipper (2009) cites the quotations of Moses:

See what the land is like: whether the people who dell in it are strong or

weak, few or many; whether the land they dwell in is good or bad;

whether the cities they inhabit are like camps or strongholds; whether the

land is rich or poor; and whether there are forests there or not.

Hippner (2009) continues by explaining "Moses is a decision maker who wants to know everything that may be relevant, as his tasking implies. He asks for reports on the economic, military, and social situation of Canaan. " (p. 1). Prophet Mohammed (SM) intensively used intelligence in all the battles against the Quaishis. For example, "on the eve of the battle of Uhud, Prophet Mohammed (SM) sent two agents to scout the area around Medina and Mount Uhud and to collect as much information as they could on the Quraishi, especially the number of men deployed against him and the area they were concentrated" (Al-Asmari, 2013, p. 101). So, "the fundamentals of war planning include an assessment of one's capabilities and gathering intelligence on the enemy to determine their strengths, weaknesses, capabilities and intentions" (Keller, 2008, p. 129-30). Further, Keller (2008) continues by informing "one of the most valuable assets that the military [and businesses] covert is intelligence of their opponents [competitors]" (p. 131). In modern days many countries have their own intelligent agents. They not only act to support the military strategies and operations, they also work as knowledge transfer vehicles to the people of the world through their open accessible web-pages. For example, CIA's (TheCentral Intelligence Agency) web-site of the US provides huge useful information and statistics on social, political and economic conditions of the countries of the world. Academics, researchers, organisations and states may be benefitted out of this

\footnotetext{
1 "The drum was used to beat the assembly and in the advance, the bell as a signal to halt. Flags were of two kinds, signalling flags and distinguishing banners" (The Art of War, p. 32).
} 
vast data/knowledge displayed there. In military the local field intelligent agents/units, work like the vehicles of knowledge transfer through the act of transmitting their collected information to their respective military units/formations during peace and war times. Such information helps the decision makes the planning and decision making process easy for the commanders. However, wrong intelligence may be suicidal for any commander and his/her under commands.

\section{3 Military Corps of Signal}

Signal Corps of any military is a knowledge transfer mechanism between the units/ commanders. In Britain, "Royal Signals provide military commanders with their information requirements and ability to command and control their forces. The methods used are at the forefront of modern digital military communications and information systems technology and the Corps strives to live up to its motto 'CertaCito', which freely translated means 'Swift and Sure' " (Royal Corps of Signal, 2015). So in brief, as the medium of knowledge transfer, they ensure the transfer of knowledge to the knowledge-recipients as fast as possible so that they may take decision and act as per the demands of the situations.

\section{4 Military Training Institutions/Schools}

Military training schools and institutions are the excellent vehicles of knowledge transfer for all ranks in the defence services. The United States Military Academy at West Point and TheRoyal Military AcademySandhurst, generally known as Sandhurst,are the two world's most prestigious military training institutions where leaders are produced. Every year many foreign countries' military cadets/personnel receive training from these institutions. Countries, usually, possessing regular military forces have their own military academies. Further, military staff colleges/universities conduct advance courses for the officers. In addition to military academies and staff colleges, fighting arms, corps and supporting arms have their own respective schools and institutions where each member of the arms and services need to undergo their respective basic and specialisation training in their respective disciplines. In addition, there is formation and unit level training round the year for every member of the military organisations.

\section{Conclusion and Future Research}

Knowledge is an indispensable asset for any organisation. It has become the life-blood for the survival and prosperity of theorganisations. It is a driving force for action. Human brains are the generators of knowledge (tacit), and after that it takes various forms (explicit). Knowledge management could achieve huge attention by the academics and the business worlds. Military units and formations could also utilise this invaluable asset into their operations. Knowledge transfer is one of the crucial elements of the knowledge management process. Knowledge transfer occurs between the knowledge contributors and the knowledge recipients. For the smooth transfer of knowledge between the knowledge actors, the selection and use of an appropriate media, e. g. vehicle is paramount. Inappropriate use of such vehicles maydistort the transferred knowledge, or transfer may not occur and such situationmay be dangerous for allunits and formations engaged with the battles. There isnumerous knowledge transfer mechanisms. In ancient days, bells and flags were used intensively in the battle fields to transfer knowledge. Drums and bells were the effective means for night warfare. Flags represents the national identity and symbol of own forces' drive. In modern days, military forces use drums, bells and flags for ceremonial purpose as well. In some parts of the globe, people use megaphone and flags to warn the inhabitants about a forthcoming natural disaster. Use of intelligence is an excellent mechanism of knowledge transfer, which was intensively utilised and engaged by the ancient Generals and leaders in the war and battle-fields. Modern days, many countries possess strong intelligence agencies and military corps of intelligence. These units/formations collect, collate and disseminate information and work as excellent knowledge transfer mechanisms for the fighting and logistics elements during the peace and times. Military Corps of Signal ensures the on-time transfer of knowledge between the units/formations. Military training institutions and schools are the brilliant vehicles of knowledge transfer, where in addition to basic trainings, specialised trainings are also provided to the military personnel of the respective arms and services. Thus the trained personnel may transfer knowledge to their colleagues and subordinates.

Future researchers may empirically examine the knowledge transfer mechanisms in any military or non-military context.

\section{References}

[1] Alavi, M. \& Leidner, D. E. (2001). Knowledge management and knowledge management systems: Conceptual foundations and research issues, MIS Quarterly, 25 (1), 107- 136 
[2] Al-Asmari, A. A. (2013). 'Origins of an Arab and islamic intelligence culture', Davies, P. H. J. \& Gustafson, K. C. (ed.) Intelligence Elsewhere: Spies and Espionage Outside the Anglosphere. Washington DC: Georgetown University Press, pp. 89-114.

[3] Albino, V., Garavelli, A. C. \&Gorgoglione, M. (2004). Organization and technology in knowledge transfer. Benchmarking: An International Journal, 11(6), 584-600.

[4] Albino, V., Claudio, G. A. \&Schiuma, G. (1999). Knowledge transfer and inter-firm relationships in industrial districts: The role of the leader firm. Technovation, 19, 53-63.

[5] Alex , B., David, B. \& Lee, S. L. (2010). Exploring the military contribution to KBD through leadership and values, Journal of Knowledge Management, (14) 2, 314 - 330.

[6] Argote, L. (1999). Organizational Learning: Creating, Retaining and Transferring Knowledge. Massachusetts: Kluwer Academic Publishers.

[7] Appleyard, M. M. (1996). How does Knowledge flow? Interfirm patterns in the semiconductor industry. Strategic Management Journal, 17 (Winter Special), 137-154.

[8] Argote, L. \& Ingram, P. (2000). Knowledge transfer: A basis for competitive advantage in Firms. Organisational Behaviour and Human Decision Procesess, 82 (1), 150-169.

[9] Argote, L., Ingram, P., Levine, J. M. \& Moreland, R. L. (2000). Knowledge transfer in organizationns: Learning from the experience of others. Organisational Behaviour and Human Decision Processes, 82 (1), 1-8.

[10] Argote, L., McEvily, B. \& Reagans, R. (2003). Managing knowledge in organizations: An integrative framework and review of emerging themes. Management Science, 49(4) 571-582.

[11] Bartone, P. T. \& Adler, A. B. (1995). Event-Oriented Debriefing Following Military Operations: What Every Leader Should Know. Washington: US Army Medical Research Unit-Europe Unit 29218.

[12] Bell, D. G., Giordano, R. \&Putz,P. (2002). Inter-firm sharing of process knowledge: Exploring knowledge markets. Knowledge and Process Management, 9(1), 12-22.

[13] British Army (2015). The Intelligence Corps. Available:http://www. army. mod. uk/intelligence [Accessed: $8^{\text {th }}$ June 2015].

[14] British National Army Museum (2015). Colonel James Skinner holding a Regimental Durbar, 1827. Available at: http://www. nam. ac. uk/onlinecollection/detail. php?acc=1956-02-27-3 [Accessed: 17 May 2015]

[15] Butler-Bowdon, T. (2010). Sun Tzu- The Art of War: The Ancient Classic. West Sussex :Capstone Publishing.

[16] Chae, B. \&Bloodgood, J. M. (2006). The paradoxes of knowledge management: An eastern philosophical perspective. Information and Organization, 16(1), 1-26.

[17] Chowdhury, D. (2009). The Determinants of Knowledge Transfer in Turkish Textile and Apparel Industry. PhD Thesis. University of Plymouth (unpublished).

[18] Connell, N. A. D., Klein, J. H. \& Powell, P. L. (2003). It's tacit knowledge but not as we know it: Redirecting the search for knowledge. Journal of the Operational Research Society, 54 (2), 140-152.

[19] Debowski, S. (2006). Knowledge Management. Sydney: John Wiley \& Sons Australia Ltd. Darr, E. D., Argote, L. \&Epple, D. (1995) The acquisition, transfer and deprecation of knowledge in service organisations:

Productivity in franchises. Management Science, 41 (11),1750-1762.

[20] Darr, E. D. and Kurtzberg,T. R. ( 2000) An inVaustigation of partner similarity dimensions of knowledge transfer. Organisational Behaviour and Human Decision Processes, 82(1), $28-44$.

[21] Davenport, T. H. \&Prusak, L. (1998). Working Knowledge: How Organizations Manage What They Know. MA: Harvard Business School Press

[22] Dimovski, V, Marič, M., Uhan,M., Đurica, N. \&Ferjan, M. (2012). Sun Tzu's "The Art of War"and implications for leadership:Theoretical discussion. Organizacija, 45 (4), 151-158.

[23] Dyer, J. H. \&Nobeoka, K. (2000). Creating and managing a high performance knowledge sharing network: The Toyota case. Strategic Management Journal, 21 (3), 345-367.

[24] Easterby-Smith, M., Lyles, M. A. \& Tsang, E. W. K.. (2008). Inter-organizational knowledge transfer: Current themes and future prospects. Journal of Management Studies, 45(4), 677-690.

[25] Edvardsson, I. R. (2006). Knowledge management and SMEs: the case of Icelandic firms. Knowledge Management Research \& Practice, 4 (4), 275-82.

[26] Farmer, B., Lasna\& Blair, D. (2015). 'Estonia stages biggest military exercise in country's history amid fears of Russian 'aggression". The Telegraph, $12^{\text {th }}$ May. 
[27] Fireston, J. M. \& McElroy, M. W. (2005). Defining knowledge management: Knowledge Management or not knowledge management? That is the question, Strategic Direction, 21 (10), 22-24.

[28] Galup, S. D., Dattero, R. \& Hicks, R. C. (2002). Knowledge management systems: An architecture for activeand passive knowledge. Information Resource Management Journal, (15) 1, $22-7$.

[29] Galup, S. D., Dattero, R. \&Hicks, R. C. (2003). The enterprise knowledge dictionary. Knowledge Management Research and Practice, (1) 1, 95-10

[30] Garaventa, E. (1998). Drama: A tool for teaching business ethics. Business Ethics Quarterly, 8(3), 535-545.

[31] George, J. S., Schwager, S. \& Canavan (1998). A guide to drama-based training. Employment Relations Today, 25(4), 15-19.

[32] Gettier, E. L. (1963). Is justified true belief knowledge? Analysis, 23 (6: Jun), 121-123.

[33] Goh, C. \&Hooper, C. (2009). Knowledge and information sharing in a close information environment. Journal of Knowledge Management, 13(2). 21-34.

[34] Grant, R. M. (1996). Toward a knowledge-based theory of the firm. Strategic Management Journal, 17 (Winter Special Issue), 109-112.

[35] Grant, R. M. (1997). The knowledge-based view of the firm: Implications for management practice. Long Range Planning, 30(3), 450-454.

[36] Gulati, R. \& Nickerson, J. A. (2008). Interorganizational trust, governance choice, and exchange performance. Organization Science, 19 (5), 688-708

[37] Hall, B. P. (2001) Values development and learning organisations of Knowledge. Journal of Management, (5) 1, 19-32.

[38] Hasnain, S. S. (2016). Knowledge Management in Non-Governmental Organisations: Towards a New Horizon. New York (USA): International Institute for Science Technology \& Education.

[39] Hasnain, S. S. (2016a). A few good knowledge transfer mechanisms: Keys to successful military operations. Archives of Business Research, 3 (4), 1-8.

[40] Hasnain, S. S., Jasimuddin, S. M. and Fuller-Love, N. (2016). Exploring Causes, Taxonomies, Mechanisms and Barriers Influencing Knowledge Transfer: Empirical Studies in NGOs. Information Resources Management Journal, 29 (1), 39-56.

[41] Hasnain, S. S. \& Jasimuddin, S. M. (2012). The Barriers to Knowledge Transfer: An Empirical Study in the Non- Governmental Organisations (NGOs) in Bangladesh. World Journal of Social Science, March 2 (2), 13515.

[42] Hensen, M. T., Nohria, N., \& Tierney, T. (1999). What's your strategy for managing knowledge? Harvard Business Review, 77 (2), 106-116.

[43] Hippner, C. (2009). A Study into the Size of World's Intelligence Industry. Msc. Thesis (unpublished).. Faculty of Mercyhurst College. Erie, Pennsylvania.

[44] Hislop, D. (2005).. Knowledge Management in Organizations-A Critical Introduction. NY: Oxford University Press.

[45] Hogberg, C. \&Edvinsson, L. (1998). A design for futurizing knowledge networking. Journal of Knowledge Management, 2 (2), 81-92.

[46] Howell, P. (2003). Indigenous early warning indicators of cyclones: Potential application in coastal Bangladesh. DiaasterStydies Working Paper 6. Benfield Hazard Research Centre. Available at: http://www. unisdr. org/files/1529_workingpaper6. pdf. [Accessed: 19th October 2011].

[47] Huber, G. (2001). Transfer of knowledge in knowledge management systems: Unexplored issues and suggested studies. European Journal of Information Systems, 10, 72-79.

[48] Inkpen, A. C. (2008). Knowledge transfer and international joint ventures: The case of nummi and general motors. Strategic Management Journal, 29, 447-453.

[49] Jasimuddin,S. M. (2007). Exploring knowledge transfer mechanisms: The case of a UK-based group within a high-tech global corporation. International Journal of Information Management, 27, 294-300.

[50] Keller,G. F. (2008). The influence of military strategies on business planning. International Journal of Business and Management, 3 (5), 129-134.

[51] Leonard, D. \&Sensiper, S. (1998): The role of tacit knowledge in group innovation. California Management Review, 40(3), 112-125. 
[52] Mace, B. \& Thomason, G. (2008). Knowledge management is combat power. Marine Corps Gazette, 92 (6), 37.

[53] Marquardt, M. J. (1996). Building the Learning Organization: A Systems Approach to Quantum Improvement and Global Success. NY: McGraw-Hill.

[54] Mu, J., Peng, G. \&Love,E. (2008). Interfirm networks, social capital, and knowledge flow. Journal of Knowledge Management, 12(4), 86-100.

[55] Ngah, R. \&Jusoff, K. (2009). Tacit knowledge sharing and SMEs' organizational performance. International Journal of Economics and Finance, 1 (1), 216-220.

[56] Nonaka, I. \& Takeuchi, H. (1995). The Knowledge Creating Company. Oxford: Oxford University Press. Pan, S. L. \&Scarbrough, H. (1998). A Socio-technical view of knowledge-sharing at Buckman Laboratories, Journal of Knowledge Management, 2 (1), 55-66.

[57] Paul, B. K. (2009). Why relatively fewer people died? The case of Bangladesh's cyclone sidr. Nat Hazards, 50, 289-304.

[58] Penrose, E. (1959). The Theory of the Growth of the Firm. New York: Wiley.

[59] Philip, W. R. \& Martin, C. P. (2009). A philosophical approach to time in military knowledge management. Journal of Knowledge Management, (13) 1,171 - 183.

[60] Richter, F. \& Vettel, K. (1995). Successful joint ventures in Japan: Transferring knowledge through organisational learning. Long Range Planning, 28 (3), 37-45.

[61] Rowe, N. C. (2009). The ethics of cyber weapons in warfare. International Journal of Cyberethics, 1(1), 20-31.

[62] Royal Corps of Signals (2015). Royal Corps of Signals. Available at: http://www. army. mod. uk/signals/signals. aspx [Access date: 30th May 2015).

[63] Scarbrough, H. (1995). Blackboxes, hostages and prisoners, Organization Studies, 16 (6), 991-1019.

[64] Scarbrough, H., Robertson,M. \&Swan,J. ( 2005). Professional media and management

[65] fasion: The case of knowledge management, Scandinavian Journal of Management, (21) 2, 197-208.

[66] Shannon, C. E. \& Weaver, W. (1949). The Mathematical Theory of Communication. Illinois: Board University of Illinois (University of Illinois Press)

[67] Singh, L. (1979). Indian Sword Strikes in East Pakistan. New Delhi: Vikas Publishing House.

[68] Sun Tzu- The Art of War: The Ancient Classic (2010). West Sussex: Capstone Publishing. aiwana, A. (2002). The Knowledge Management Toolkit: Practical Techniques for Building a Knowledge Management System. NJ: Prentice Hall.

[69] Thompson, L., Gentner, D. \& Lowenstein, J. (2000). Avoiding missed opportunities in managerial life: Analogical training more powerful than individual case training. Organizational Behavior Human Decision Process, 82 (1), 60-75.

[70] Van Wijk, R., Jansen, J. J. P. \& Lyles, M. A. (2008). Inter- and intra-organizational knowledge transfer: A meta-analytic review and assessment of its antecedents and consequences. Journal of Management Studies, 45(4), 830-853.

[71] Wathne, K., Roos, J. \& von Krogh, G. (1996) 'Towards a theory of knowledge transfer in a cooperative context' in von Krogh, G. and Roos,J. (eds. ) Managing Knowledge: Perspectives on Cooperation and Competition. London: SAGE Publications Ltd. pp. 55-81.

[72] Wong, Y., Maher,T. \& Lee, G. (1998). The strategy of an ancient warrior: An inspiration for international managers. Multinational Business Review, 6(1), 83-93. 